\title{
10
}

\section{Race, Animal Bodies and Religion: Sacrifice, Sensory Politics and Public Space in South Africa}

\author{
Shaheed Tayob
}

\section{Suspicions of Sacrifice: Crowds, Race and Animal Bodies}

On Saturday 14 October 2017, a Muslim family held their son's seventh birthday party in a public park in Woodstock, a rapidly gentrifying neighbourhood close to the centre of Cape Town. Re-zoned as a Coloured residential area during apartheid, the neighbourhood had subsequently become a racially mixed area comprising Malay Muslims, Coloured Christians, Jews and Portuguese. ${ }^{1}$ Woodstock is very close to the now mostly vacant garment factories in Salt River, once a major locus of economic activity. In the 1990s, low-cost Chinese imports dealt a blow to the economy of the area. However, Woodstock is a short drive from Cape Town's Central Business District and the famous Atlantic Seaboard. During the 2000s, the neighbourhood became a target for gentrification as young couples and investors from predominantly white middle-class

\section{S. Tayob $(\bowtie)$}

Stellenbosch University, Stellenbosch, South Africa e-mail: shaheedt@sun.ac.za 
backgrounds found opportunities in redeveloping the sometimes decrepit, poorly maintained Victorian-style houses in the area.

A day before the birthday party, the family had obtained a permit from the local municipal authority to set up a petting zoo for their son and his friends and family. The young boy was passionate about animals and had aspirations to become a veterinarian. On the day of the party, a group of friends and family were celebrating in the park, accompanied by 'chickens, roosters, birds, rabbits, a tortoise and a dwarf goat'. During the party, a local white resident of the area, Mary Wallace, ${ }^{2}$ was out walking her dog. In an interview I conducted with her, she explained that, approaching the park, she noticed 'that the children's section of the park was really full of people' and that her dog was becoming agitated.

So we were unsure about [whether] to go or not, we hadn't had a good look at what was going on. The park was extremely full, and there was a goat tied to one of the poles of the swings with a very short rope [motions with her hands to indicate the rope was shorter than from her hand to elbow] and the goat was screaming. I saw the goat, said to my husband 'there's a goat tied to a pole with a very short rope', and my husband said to me, 'Let's get the dogs out of here, they're gonna freak out completely'.

She described herself as a concerned animal rights activist, who made the decision to share a post on the neighbourhood's Facebook page, this being a safe space where she might find advice and support. She rushed online and posted the following:

Help! There is a goat tied to a pole in the children's park in Queens Park. Huge crowd of people. Goat is screaming what to do? Help.

She recounted being hysterical and overcome with horror at what she perceived as the ill treatment of the 'screaming' goat. She contacted the local branch of the Society for the Prevention of Cruelty to Animals (SPCA) to inform it that there was a goat in the park being held on a very short rope. Fellow residents advised her to alert the police as well. The police enquired as to whether the goat had in fact committed a crime. 
As the furore unfolded, it was clear that her concern for the well-being of the now anthropomorphized goat had evolved into a racially charged discussion about the possible horrors in the park. Concerned residents, all white, rushed in with advice and support that clearly drew on tropes of racialized, barbaric otherness. Wallace exclaimed that she 'ran away' from the scene. In a comment of support, another woman explained that she too had ventured nearby, noticed the huge group and left. However, she was there long enough to note the 'strong smell of braai' (barbeque). Others chimed in with suspicions of bestiality, and assertions that slaughter could be the only possible explanation: 'What would they want with a goat? Unless they were having sex with the goat?' Wallace did step in to calm down the chorus of suspicion and accusations with a 'more rational' approach by doubting whether 'it would be possible to slaughter, skin and prepare an animal in that space of time'. However, during the early exchange there was no awareness that the tropes through which the accusations, suspicion and horror were being articulated actually drew on a long history of racial and colonial typecasting and denigration.

As the discussion, concern and fear circulated, it was brought to the attention of a prominent Muslim social media 'influencer' called Aisha Baker. Present at the birthday party, Baker tweeted about the incident, drawing attention to the automatic association between crowds, animals and fear that had transpired. From then on, the issue went viral and appeared in several newspapers. The responses of the general public were a mixture of humour and exasperation that another instance of racial profiling had raised its head among the South African public. The father of the boy later turned to social media with a humorous response about having seen 'suspicious Caucasians' lurking in the park and offered advice to Wallace that 'it would have been prudent to approach us and enquire'. He specifically cast a critical eye on those who consider themselves 'saviours to humanity', by which he meant the 'previously (and currently) advantaged Cape Town elitists'. In his response, it was clear that he was treating the incident as indicative of the nation's need to overcome its racial divisions and the necessity for white liberals to move beyond the paternalist mentality of the saviour. ${ }^{3}$

The event signalled the increasing fragility of the South African public sphere, in which race has resurfaced as a topic of debate, controversy and 
political currency. Emerging from the concerns of a committed animal activist and vegan was a racially charged debate on questions of transformation, paternalism and access to and control of public space. The Facebook group discussion clearly revealed the normative assumptions about animals, race and public spaces evident in the embodied responses of the white liberal middle-class participants in the Facebook group. The divergent responses between suspicious online commentators and those at the party illuminates the split nature of South Africa's publics, here not around questions of language (Rajgopal 2001) but about the right to access and use public space. In speculating about what was taking place in the park and the motives of the family arranging the party, the discussants in the neighbourhood Facebook group, like many neighbourhood watch groups around the country, spoke as concerned residents and property owners of a particular neighbourhood (Dixon 2018), not concerned citizens. Alluding to the possibility of the goat being sacrificed, the hysteria reveals the explosive potential of animal sacrifice to expose entrenched normativities and assumptions about particular kinds of people and particular kinds of religious practice in public spaces in South Africa.

\section{Skaapgate: Sacrifice, Ancestors and Exorcizing Racism}

On 23 December 2018 at 8 pm, a private security company, Professional Protection Alternatives (PPA), shut down a popular public beach at Clifton, along the famous Atlantic Seaboard. Present during the security operation was the Western Cape Provincial Secretary of the African National Congress (ANC), Faiez Jacobs, as well as a prominent lawyer and director of the Women's Legal Resource Centre, Seeham Samaai. Jacobs and Samaai were out celebrating an annual family picnic. Just before $8 \mathrm{pm}$ they were approached and asked to leave the beach. Jacobs and Samaai recognized that the enforcers were a private security company and took to Twitter to publicize what they considered an incursion of private interests into a public space. The closure of the beach was viewed 
as a return to apartheid practice where the presence of non-white people in a public space was regulated through police-imposed curfews. The activity of PPA on the beach was read as another instance of the way in which neoliberal privatization was reproducing many of the old inequalities of access (Wagner 2015; Schneider 2010; Comaroff and Comaroff 2017).

In response to the public outrage, both the city of Cape Town and the PPA were asked to explain the incident. Initially, the PPA claimed that they had not closed the beach; instead, they had been assisting the City's law enforcement officers in a security operation after two teenagers had allegedly been raped. 'Two 15-year-old girls ... had been raped and were waiting on SAPS. This was why Law Enforcement closed the beach. [Every] other night it has been open to anyone that complies with the by-laws which Law Enforcement enforces' (Maphanga 2018). Describing the chaos on the beach and the need for control, the statement claimed that the PPA had both closed the beach in aid of the police and not closed the beach. Contradicting the PPA's statement, the spokesperson for the South African Police Force (SAPS) released a statement saying that 'Preliminary findings of the SAPS investigation indicate that no rape was registered at Camps Bay SAPS' (Evans 2018). She did confirm that a report of sexual assault had been investigated the day before the PPA incident at Clifton. Finally, five days after the event on 28 December 2018, the City of Cape Town's mayor, Dan Plato, released an official statement to clarify the city's relationship with PPA and to attack what had since then developed into a racialized and politicized uproar in the national newspapers and on social media. According to Plato, the PPA was not in fact operating under the auspices of the city and had no authority to conduct security operations on a public beach. However, he also added that the incident could not possibly be considered racist because 'they asked people of all races to leave and did not single out any race groups' (Chambers 2018). Two months later the PPA and the city both presented their cases to a Portfolio Committee on Environmental Affairs, along with eye witnesses, where they both maintained once again that the beach had not in fact been closed on that day and that the beachgoers were advised rather than forced to leave (Gerber 2019). 
As the event unfolded, it was clear that another public incident regarding race and access to public space had reared its head in South Africa. Competing political parties vied with one another to establish their version of events, either as proof of the continuation of apartheid practice or as an unfortunate incident that was about public safety and order rather than race. The fumbling statements by the police and the city, and the highly politicized arguments of opposition political parties took place a mere five months before the national elections. The city of Cape Town and the province of Western Cape were controlled by the main opposition party in South Africa, the Democratic Alliance. The incident thus provided ripe fodder and political mileage for the ANC and other parties in the elections.

However, the widespread public anger that the incident had unleashed exceeded the interests of the political parties. Indeed, for many, the way in which false claims of rape were used to justify the imposition of public order was clearly indicative of racial policing. The notion of an unruly and violent black crowd, together with claims and fears of sexual violence and a general lack of order, is a racial and colonial trope that has been powerful in authorizing violence against black South Africans (Rauch and Storey 1998; Shefer and Ratele 2011). Immediately a group of activists, politicians, academics and NGOs came together to form the Black People's National Crisis Committee (BPNCC). Many who joined the group had spearheaded the Rhodes Must Fall campaign of 2015, which eventually led to the removal of Cecil John Rhodes' Statue from its prominent position at the University of Cape Town. Included among the group and leading the event was Maxwele Chumani, famous for throwing faeces on Rhodes' statue as part of a politics of disgust designed to awaken South Africans to the country's continuing economic inequalities and the need for radical change. Continuing in that vein, Xolani, an organizer of the BPNCC whom I interviewed, stated that the crisis was a crisis of racism. He argued that the incident highlighted the continuation of racism in South Africa: 'I know how these people are when they see a congregation of black people in a space. All their irrational attitudes and presuppositions of black people come to the fore ... and they always want to police in a manner that seems to reproduce notions of apartheid.' For the Committee, the incident was linked to an ongoing crisis in the 
country, in which racism has been officially abandoned as state policy but lingers on in everyday life, spatial politics and neoliberal security action.

After much deliberation, the BPNCC decided to sacrifice a sheep on the very beach that had been at the centre of the controversy. On 28 December 2019, very much to the interest of the media and animal rights groups, the organizers arrived on Clifton beach to slaughter a sheep. Immediately following the slaughter, a divided public again emerged, with predominantly black commentators celebrating the act as the assertion of black selfhood in South Africa, while the dominant response from mostly white middle-class South Africans was one of shock and horror at a barbaric act they felt was detrimental to the very cause of the anti-racist protests. This time, however, Wallace supported of the slaughter. She said she had made a choice between siding with 'black outrage and the claiming of the space and the slaughtering of the sheep' and 'white privilege that effectively told black people that "You can't do this on our beaches".

Unlike the previous incident in Woodstock, this time an animal was in fact sacrificed. In Woodstock the presence of black bodies in a public space, Wallace's horror, anxiety and concern, and the clearly racist posts by the neighbourhood Facebook group combined to provoke public outrage and debate over the insidious ways in which race and access to public space are mediated and controlled. In Clifton, however, a security incident which bore the ghostly traces of a colonial and apartheid past was challenged by a group of activists, scholars and politicians. This time the act of sacrifice was a way of claiming space and challenging the privatization and re-racialization of beaches in South Africa. As we shall see, the exact form the sacrifice took speaks to a legacy of African traditional religion, sensory politics and particular kinds of public space in South Africa.

\section{Religious Nationalism in a Post-apartheid Neoliberal Moment}

Peter van der Veer's seminal contribution to the analysis of religious nationalism in India challenged Eurocentric assumptions about the inherent secularity of modern nation-state formation as a break from the traditional identities, world-views and practices of a pre-modern past. 
For van der Veer, religious discourses and practices are constitutive of the changing social identities that are invested in the formation of national identities (van der Veer 1994: ix). Importantly 'these identities are not primordial attachments ... but specific products of changings forms of religious organization and communication' that articulate 'discourse on religious community and discourse on the nation' (van der Veer 1994: x). Van der Veer thus argued for attention to be paid to the 'fundamental orienting conceptions for the world and of personhood' (van der Veer 1994: 8) that are invested in the formation of the modern nation-state. In religious nationalism practitioners from competing religious traditions clash over different conceptions of the way religion, ethical values, personhood and human-animal relations are calibrated. For example, Gandhi's claims regarding 'an all-embracing Indian spirituality' centred on his appropriation of the Hindu discourse of non-violence (ahimsa) and support for cow protection that alienated Muslims, who 'had their own discourse on universal religion' and animal sacrifice (van der Veer 1994: 95-96). Given that the 'public sphere is not an empty space for carrying out debates' but is 'constituted by the sensibilities-memories and aspirations, fears and hopes_of speakers and listeners' (Asad 2003: 185), it follows that different sensibilities informed by different religious traditions may lead to conflicts over the proper place and practice of religion that are also conflicts over the shape and future of the nation.

In South Africa, apartheid entailed the forceful denigration of people and religion. The post-racial and post-mono-religious state thus authorizes the flourishing of religion in both state and private affairs in surprising and unexpected ways in an attempt to 'turn diversity from an obstacle to nationalism into a national resource, seeking not uniformity but unity' (Chidester 2012: 2). The outcome is a tension between 'political secularism and ... a proliferation of religious representations' that are authorized in public life (Tayob 2018). For example, in constitutional court hearings over the practice of minority (non-Christian) religious observance in schools, school and parent-teacher bodies' attempts to mobilize particular Christian definitions of religion are rejected by the court as contravening the constitutional right to religious freedom (Tayob 2017). The South African constitution aims to accommodate not just the diversity of religious beliefs, but also the diversity of religious practice. As we saw in the 
case of the sheep sacrifice on Clifton beach, the South African state and national police were unwilling to sanction the act as a contravention of public health and safety ordinances, deferring to the constitutional right to practice religious freedom instead.

For David Chidester, the state formation of religion in the postapartheid state reveals the contested dynamics of the sacred in the production of what he calls 'wild religion'. Wild, for Chidester (2012: 3), refers both to the 'untamed, undomesticated, uncultivated, unrestrained, unruly and dangerous', as well as the 'dynamic, natural, extraordinary, enthusiastic, ecstatic, invigorating'. Chidester's invocation of the 'wild', sequestered from a colonial and contemporary politics of Otherness, fails to appreciate the political and philosophical entanglements of religion with colonial and apartheid-era discourse (Chidester 1996). Articulating the wild as good and bad reduces these categories to descriptive markers rather than deeply embedded moral and political judgements with significant normative power. It misses the way in which religious practice is closely tied to normative assumptions and sensibilities on the kinds of behaviour and practice that are acceptable in public life. And while I agree with Chidester that African traditional religion must be understood as an open set of resources that are always embedded within the world, wherein sacrifice, ancestor veneration and initiation are variously configured, it is important not to lose sight of the potential for expressions of a sensory politics within it. As we shall see, the BPNCC appropriated a 'traditional' African traditional religious practice of animal sacrifice for a political end in an attempt to contest the historically embedded racialized assumptions about African traditional religion and the contemporary politics of privatization that excludes the majority of black South Africans from certain kinds of elite spaces. Using religion, they challenged a contemporary politics of racial and religious exclusion, in the process imagining the inclusive national space to come.

I therefore argue for attention to be paid to the sensory politics contained within competing discourses and practices of religion in public spaces. Much as the post-apartheid state sought to link its authority and heritage claims to sensory calibration (Jethro 2020), the emerging radical politics around student protest movements and against neoliberalism have also entailed a sensory contestation. 
This chapter thus treats the examples described above as instances of competing ethical and political claims to selfhood, sensory propriety and the nation. The post-apartheid state, with its deep commitment to plurality, together with the increasing power of private interests and the emphasis on private property and self-organization in the contemporary neoliberal environment, are important in understanding the fraught contestations over race, religion and public space in South Africa today. As scholars have argued, neoliberal policies that champion neutral ideas of the free market and the flourishing individual very often reproduce and facilitate the re-emergence of race and caste as markers of difference (Pinto 2006). Across the world, housing market booms, gentrification and privatization is accompanying the resurgence of old class and race identities, now under the guise of 'brightening' an area or 'community upliftment' (Hyra 2017). Under these conditions, the practice of religion in public spaces becomes linked to a politics of self and community that establishes and challenges norms of religious practice, sensory propriety and access to and use of public spaces beyond the purview of the state. This chapter therefore calls attention to the limits of a state-centric approach to anthropology in South Africa remaining alert to the power of private actors as they articulate a link between religious practice, public space, private property, sensory propriety and the flourishing individual.

Animal sacrifice is a perfect practice for understanding the competing normative assumptions about religion and racial Others as they relate to the politics of religion and public spaces in South Africa. Sacrifice is a powerful means for the production of sacred politics as a 'religious ritual of political sovereignty' (Chidester 2012: 181) that is central to the foundational myths of nationalism (Anderson 1983). However, animal sacrifice as a trope of racial and barbaric Otherness has deep colonial roots that linger in normative assumptions about a hierarchy that places proper spiritual religions over primitive material religions (van der Veer 2011). In a brilliant analysis of the interplay between the anthropology and philosophy of sacrifice, Denis Keenan identifies 'Christo-centric evolutionism' and the construction of 'worldwide typologies' as central to 
'numerous late nineteenth-century and early twentieth-century theories of sacrifice' (Keenan 2005: 10). According to the evolutionary view, the sacrifice of Jesus as God himself signals the highest form of sacrifice, bringing an end to sacrifices of transaction in favour of the symbolic commemorative sacrifice of communion. In this view, religions that continue animal sacrifice are primitive and barbaric, being ranked according to a classification of worldwide typologies of religion from supposedly savage, animist and fetish religions to higher forms of moral and spiritual religion (Chidester 1996). The hierarchy of religions was of course one of the many hierarchies of civilization and people that marked nineteenthcentury social theory. It is therefore no coincidence to find Africans being interpreted as the bearers of a lack of civilization, racial degradation and primitive religious mentalities. In South Africa, this confluence is all the more striking given the long history of settler colonialism and apartheid's racial state policies, with their intimate links to Calvinist Christianity and theories of racial and civilizational difference (Dubow 1992). I argue that the post-apartheid state's desire to insert animal sacrifice at the centre of rituals of national belonging, which Chidester highlights, must also be understood as a response to the history of the denigration of African religious practices, now asserted from a position of power that is no longer subject to a Eurocentric hierarchy of value. Viewed from the long history of colonialism and apartheid, animal sacrifice in public entails a sensory politics of selfhood and an assertion of African subjectivity.

The furore that emerged around Wallace's seemingly innocent concern in the park at Woodstock and the decision of a group of activists to respond to the security action on Clifton beach with an animal sacrifice must be read as emerging from this contested space of religion, race and private property interests in South Africa. In these moments, we find that articulations and redeployments of religious practice in public spaces reveal the competing desires, normative assumptions and sensory politics of private individuals competing over the use and access to public spaces in South Africa. 


\section{The Return to Race in South Africa: From Rainbow Nation to Racial Politics}

After apartheid, South Africa was celebrated as a poster-case for the peaceful transformation to a post-racial and multi-racial society, a 'rainbow' nation (Niehaus 2014). The first parliament was established as a 'government of national unity' designed to grant cabinet representation to all parties that had won above 10 per cent of the national vote. The aim was to ensure a smooth and inclusive transition. Central to the politics of transition was the establishment of the Truth and Reconciliation Commission (TRC), tasked with collecting testimonies of individual apartheid-era atrocities in exchange for an amnesty for the perpetrators and reparation for the victims. Aiming for confessional, restorative justice, the TRC was central to the post-apartheid state's desire to forge a nation of multiple communities united under constitutional law. However, for Mahmood Mamdani, the TRC 'reduced apartheid from a relationship between the state and entire communities to one between the state and individuals' (Mamdani 2002: 34). The individualization evident in the TRC process points to the way in which a neoliberal politics of state and consumer-citizen relations had started to take hold.

For critics of the 'rainbow nation', it became increasingly clear that the imperative of liberation during apartheid had been compromised by the now global imperative towards liberalization. Sociologists argued that the balancing act had in fact contributed to 'greater inequality in the distribution of incomes in society as a whole', as well as 'employment losses' (Nattrass and Seekings 2001: 484). By 2018, it had become clear that inequalities were still highly racialized, with white incomes increasing more rapidly than those of other races (Friedmand 2015: 47). Steven Friedmand argues that one of the reasons for the continuity of inequality is the maintenance of 'cultural assumptions' relating to the superiority of Western values and lifestyles, which were previously the exclusive domain of white liberals, but were now shared by the new black elite (Friedmand 2015: 50; also see Turner 1972). Neoliberal aspirations to become 'world class' produced a desire to emulate Northern patterns of lifestyle and livelihood, rather than devise means to combat local urgencies of inequality, unemployment and a lack of access to education (Friedmand 2005). 
In the end, those who benefit most from neoliberal economic policies are the relatively advantaged white and Indian-origin middle classes. The widening inequalities and persistence of everyday racism set the scene for the re-irruption of an ordinary politics of race. This was most forcefully articulated by student protest movements such as the Rhodes Must Fall campaign, which achieved international fame through its calls to decolonize education, transform institutions of higher education and combat insidious, everyday forms of racial exclusion. As already noted, this protest began when Chumani Maxwele threw faeces at the statue of Cecil John Rhodes in a 'visceral material act of disgust' that 'actualised a growing mood of discontent among South Africans' (Pillay 2016: 156). The protests brought together critical race theory, South African Black Consciousness philosophy and critiques of neoliberalism to attack both the state and the university system (Naidoo 2016). Feeding off critical scholarship, the activists argued that 'the zeitgeist of Nelson Mandela's post-1994 government disabled radical activism by foregrounding narratives of peace, reconciliation, forgiveness, and unity'. The movement opted instead for 'foregrounding exclusion, poverty, broken political promises, and privilege' (Pillay 2016: 156). Clearly, the politics of animals, race, sacrifice and access to public spaces must be understood in the context of increasing racial inequality and the return of racial consciousness in South Africa's public sphere. Central to these contestations is a sensory politics through which substances, sounds and bodies become the medium for a radical politics to emerge that imagines a new, reconfigured nation.

\section{Sacrifice as Politics: Cleansing Cape Town and Attacking the Nerve Centre of Racism}

For the organizers of the public sacrifice, the racist excuses and behaviour of the private security guards, in conjunction with the area's residents and the cover-ups by the City of Cape Town, required immediate action. After much deliberation, they decided that an animal sacrifice should be performed. In an interview I conducted with Xolani, a BPNCC member, he explained that the committee had experience of the power of animal 
sacrifice as a tool of disruption during the Fees Must Fall protests, when, in the middle of extensive private security brutality, the group decided to slaughter a sheep on the University of Cape Town campus-'and we did it, and the animal rights people went crazy, so we already knew they were going to go crazy'. Given the BPNCC's awareness of the power of public sacrifice to create shock, concern and hysteria amongst their mainly white middle-class opposition, it was decided that slaughter was the appropriate response. However, the decision to perform a public sacrifice was not only inspired by a politics of disgust and disruption, but also by a desire to deploy a version of African traditional religious practice in a public space. As we will see, the organizers intentionally curated and adjusted an African traditional ritual practice at the intersection of cultural and religious assertion and the politics of race and inequality in South Africa.

Sacrificing a sheep was therefore considered a powerful political response rather than an authentic replication of an African traditional religious practice. Xolani and Thato, who were active in the BPNCC organizing committee, described sacrifice as a practice that 'connects us with the other world, the world of the ancestors'. The spilling of blood was thus deemed a way 'to show that we are sacrificing this beast in order to start a conversation with the ancestors ... to invoke them, to make them see that we are young people, we might not know everything, but we know that they must come to our rescue'. The sacrifice was thus staged as an invocation of the ancestral spirit of Makhanda Nxele, a well-known anti-colonial warrior in the Xhosa community and once a prisoner on Robben Island who is believed to have escaped imprisonment by swimming to the Cape in a bid to liberate his people. However, he did not make the journey, and memories of his failed rescue continue to resonate in everyday speech as a trope of endless waiting, as well as an ordinary reminder of the history of loss through colonialism (Wells 2012). ${ }^{4}$

Invoking the spirit of a famous warrior as an ancestor represents a creative appropriation and re-articulation of an established ritual practice. Usually, in African traditional religious practice, the ancestors are invoked as a link to the homestead and household and are called upon for protection from potential misfortune and strife (Chidester 2012: 27). Retaining the importance of animal sacrifice as a source of protection and power, in Clifton the family and homestead were extended to include all previously 
disadvantaged and oppressed black South Africans and anti-colonial heroes in the political and economic struggle against racism and inequality. The BPNCC was aware of the creative appropriation and redeployment of sacrifice for political ends, and anxious not to cause offence to black South Africans. They decided to avoid slaughtering a goat, a powerful symbol of communication with the ancestors in African traditional religious practice. They also eschewed what they considered the pacifying influence of African religious leaders and the Council of Traditional Healers, who they thought would conduct a 'purely cultural ceremony' marked by minute ritual concerns, yet free from any 'fire' and political currency. The sacrifice thus drew on powerful symbols of African traditional religion, recalibrated in crucial ways so as not to cause offence to fellow black South Africans, and to mark the moment as a political claim against the privatization of public space.

In staging the sacrifice, the sheep was first made to drink the sea water at Clifton beach in order to imbibe the spirit of Makhanda Nxele, who had drowned in that very ocean

so that the spirit of Makhanda can enter us, and we will consume it and it will cleanse us, and it will enter us and strengthen us in order to fight the racists. So, it was a two-pronged situation where we are saying we are exorcising racism and racist attitudes in the white community and also strengthening ourselves against the racists, to not just be victims of racism but to be proactive in finding solutions to a problem which we never created. (interview with Xolani and Thato conducted by the author)

The sacrifice was therefore clearly articulated as part of a political programme that required the power of the African ancestors, the interpretive realm of which was extended to include all the heroes of the anti-colonial struggle, as well as symbols of independence, including Shaka Zulu and Nehanda. ${ }^{5}$ The goal of this political deployment of sacrifice was to disturb what Xolani called the 'nerve centre' of racism in South Africa, a symbolically charged, historically informed, material and metaphoric evocation that ties the history of colonialism in South Africa to spatial apartheid, neoliberal gentrification and the politics of animal sacrifice and Otherness: 
Cape Town in the South African imagination seems to be a colony. Cape Town operates differently than the other cities. Cape Town's spatial planning is very aggressive in demarcating spaces. So, when we say it's the nerve centre, in a sense we mean that colonial settlement finds its hydraulics here, how it operates, it's just in the everyday. So, Cape Town is the nerve centre of South African racism. Cape Town is the microcosm of the vision of racists of what they would want South Africa to be like. The ideas of colonial settlement and the ideas more importantly of colonial expansion are eminent in this place. And also, all the apartheid intellectuals, some of them come from Stellenbosch. Those who incubated the idea of apartheid and nurtured it, so Cape Town then becomes the laboratory of South African racism.

Treating Cape Town as the nerve centre of racism draws attention to the history of the first colonial settlement, the aggressive spatial segregation that many argue continues in the post-apartheid context, and to the fact that some of the most influential architects of apartheid stem from the region. Explaining the latter, Xolani was clear to differentiate the 'subtle' and 'sophisticated' racism of Cape Town from the aggressive racism of right-wing groups like the Afrikaner Weerstandsbeweging (AWB). The significance of the Atlantic Seaboard was further emphasized as a space that, through 'neoliberalism' and privatization, has resisted transformation, while maintaining the poster-card image of the beauty of the Cape. Finally, the metaphor of the nerve centre was extended to the outrage expected by animal rights activists and 'white liberals' who were surely 'going to be up in arms' over the sacrifice. This, for Xolani, was evidence 'that actually they don't want black people to practice their cultural practices'. The sacrifice was thus a carefully calibrated and staged event that sought to call on the spirit of the ancestors of anti-colonial resistance and black African power while simultaneously drawing attention to the continued perpetuation of racism in South Africa. Since acts of sacrifice are very common in the public spaces of black South African townships, this specific act was not merely about claiming public space; rather, it was about drawing attention to the perpetuation of racist attitudes and practices in predominantly white upper-class spaces in the city. In doing so, the protestors activated a long history of anti-colonial resistance. As early 
as the 1830s, the very rituals that were considered evidence of barbaric Otherness and 'sensory disorganization' were 'intentionally deployed by indigenous ritual specialists in opposition to colonial domination'. These included 'loud drumming and chanting' outside the colonial settlements to frighten settlers (Chidester 2012: 193).

The event was also a rejection of liberal paternalism, which they understood as central to the dominant white middle-class condemnation of animal sacrifices. This was specifically articulated in response to animal rights activists and vegans who attended the event in an attempt to convince them to 'practice our traditions without harming the animals'. For Xolani, this assertion was nonsensical and paternalist:

What gave them the gall that we can't practice our traditional [customs] and our traditional customs are harming animals? Are they the spokespeople of animals? Because we have been doing this since time immemorial, right? You can't just wake up and you are 21 and you tell us that all of black people are wrong in slaughtering because you have just come to some vegan consciousness. Haibo! [an expression of surprise]

Rejecting the association of animal welfare with the ending of sacrifice was not a rejection of ethical relations with animals but rather an assertion of an independent subjectivity and a critique of liberal paternalism:

veganism must be taken away from racist discourse, we must have radical black people who will reintroduce us to veganism in a better radical way, in a manner that respects our customs and ambitions and enriches them. The veganism that we need will take into consideration that black people are black people who slaughter. Won't force its logic and collapse everything. If you come with the conclusion that as black people, we must stop slaughtering it must come from us.

Here we find Xolani and Wallace coming together in agreement that the paternalism in certain strands of veganism that is intolerant of other cultures and which sidelines issues of racism in favour of animal welfare is untenable. In the South African context, where African traditional religion deserves recognition and value, there need to be more nuanced and 
sensitive discussions about ethics, animals and access to public space. Performing animal sacrifice in this context is a powerful symbolic and material articulation that pushes back against long-held colonial stereotypes, as well as more insidious and everyday forms of contemporary racism and marginalization. The public sacrifice performed a powerful Fanonian moment, whereby the activists appropriated a denigrated practice as a material and visceral force for the assertion of selfhood, community and dignity aimed at a new life and a new set of values not subsumed into European and colonial hierarchies of race, development and civilization (Gibson 2016). ${ }^{6}$ Here, the very object of Otherness as viewed from the dominant colonial frame is appropriated and used as a weapon of political and ethical claim-making. The issue is not simply about the question of animal life as an isolated ethical issue, but about the way in which animal sacrifice has been central to the history of racism, colonialism and taken for granted assumptions of African Otherness. For the organizers and supporters, animal sacrifice was intimately tied to imagining a future and a radically transformed nation.

The practice of sacrificing animals in public spaces as a political act aimed at forging a new claim to such spaces was facilitated by the South African state's professed accommodation of diverse religious practice. The deputy provincial police commissioner, Hendrick Burger, was on Clifton beach on the day of the sacrifice. He had been contacted earlier by Cape Town City's mayor, Dan Plato, regarding the South African Police Service's plans to stop the slaughter. The mayor agreed that some of the city's by-laws were being violated but remained unclear regarding the exact offence. Furthermore, Burger confirmed that private charges had been laid for contraventions of the Animal Cruelty Act and Meat Safety Act. Having attended the event, he told the parliamentary committee that no evidence of animal suffering was noted, and that the Meat Safety Act did not apply to slaughter for private consumption or for cultural or religious purposes (Makinana 2019). Refraining from judgement, the South African state authorized the sacrifice, revealing the complexities of the dispute between political secularism and religious freedom in South Africa. 


\section{Conclusion}

The controversy over the goat at the birthday party in the Woodstock park and the carefully calibrated animal sacrifice on Clifton beach bring to the fore the deeply divisive politics of race, religion and access to public spaces in South Africa. Given the long legacy of racial segregation, the post-apartheid state is cautious about legislating on religions or culture. This means that claims to regulate religious practice according to universal laws concerning the use of public space or the slaughter of animals are often ruled in favour of religious and cultural rights. As we saw, the provincial commissioner was unwilling to enforce a universal law concerning animal cruelty and slaughter when taking the religious rights of the sacrifice community into account.

In contemporary South Africa, debates over the state of the nation and its future turn on questions of property and land redistribution (Levin and Weiner 2008), and the increasing privatization of public space (McDonald and Smith 2004). Central to these contestations is a sensory politics that links particular kinds of bodies and substances to different discursive and material formations of religion. Private actors bring their own political and religious values into the public arena in a bid to control urban space as landowners and rate-payers. In this contested terrain, the political articulation of an African traditional religious practice is both a means of asserting its value and dignity and of contesting the long history of the marginalization and stigmatization of African traditional religion, culture and people.

The politics of holding animal sacrifices in public spaces reveals a sensory concern over the proper place of certain bodies, substances and practices. As contestation over religious practice in public spaces is articulated in terms of private property rights, land ownership and neighbourhood access, we need to pay attention to the sensory politics of religion that is expressed therein. This chapter therefore argues for more research on the practice of religion in public spaces that consciously challenge prevailing notions of religious and sensory propriety. In particular we should recognize how marginalized groups around the world deploy religious practice as a sensory challenge through which to assert a distinct subjectivity, selfhood and inclusive citizenship in imagining a nation to come. 


\section{Notes}

1. The term 'Coloured' is a South African racial category for people of mixed African and European descent.

2. The respondent asked to remain anonymous.

3. While conducting this research, I was specifically asked to keep first names anonymous. For this reason, I have also excluded the links to their online posts.

4. Among Xhosa-speakers the phrase 'Ulindele ukubaya kwaNxele' means 'we are waiting for the return of Nxele (Makhanda Nxele)'. Thato explained the phrase as follows: 'If your mother says you must go to Pick n Pay (grocery store) and you take two hours to return, they would say, "we were waiting for the return of Nxele."

5. Nehanda Nyakasikana led the Shona rebellion of 1896-1897 against European rule in Zimbabwe (Hawkins 2018).

6. I am indebted to Prof. David Theo Goldberg for sharing this insight while chairing a panel on Race, Religion and Public Space in South Africa, at a conference on Racism and Religion hosted by the Center for Multidisciplinary Research on Racism (CEMFOR) in 2019, where I presented a version of this paper.

\section{References}

Anderson, Benedict. 1983. Imagined Communities: Reflection on the Origin and Spread of Nationalism. London: Verso.

Asad, Talal. 2003. Formations of the Secular: Christianity, Islam, Modernity. Stanford: University Press.

Chambers, Dave. 2018. Clifton Has Become a Political Football, Says Cape Town Mayor Dan Plato. Timeslive. 28 December. https://www.timeslive. co.za/politics/2018-12-28-clifton-has-become-a-political-football-sayscape-town-mayor-dan-plato/.

Chidester, David. 1996. Savage Systems: Colonialism and Comparative Religion in Southern Africa. Cape Town: University of Cape Town Press.

- 2012. Wild Religion: Tracking the Sacred in South Africa. Berkeley: University of California Press.

Comaroff, Jean, and John L. Comaroff. 2017. The Truth about Crime. Johannesburg: Wits University Press. 
Dixon, N. 2018. Stranger-ness and Belonging in a Neighbourhood WhatsApp Group. Open Cultural Studies 1 (1): 493-503. https://doi.org/10.1515/ culture-2017-0046.

Dubow, Saul. 1992. Afrikaner Nationalism, Apartheid and the Conceptualization of 'Race'. Journal of African History 33 (2): 209-237.

Evans, Jenny. 2018. Clifton Beachgoers Report 'Attempted Sexual Violation' of Teen. News 24. 27 December.

Friedmand, Steven. 2005. Getting Better than "World Class": The Challenge of Governing Postapartheid South Africa. Social Research 72: 757-784.

- 2015. The Janus Face of the Past: Preserving and Resisting South African Path Dependence. In The Colour of Our Future: Does Race Matter in Post-apartheid South Africa? ed. Xolela Mangcu, 45-63. Johannesburg: Wits University Press.

Gerber, Jan. 2019. City of Cape Town, PPA 'Sang from the Same Hymn Sheet' on Clifton Saga. News 24. 4 February. https://www.news24.com/news24/ SouthAfrica/News/city-of-cape-town-ppa-sang-from-the-samehymn-sheet-on-clifton-saga-20190204.

Gibson, Nigel C. 2016. The Specter of Fanon: The Student Movements and the Rationality of Revolt in South Africa. Social Identities 23: 1-21. https://doi. org/10.1080/13504630.2016.1219123.

Hawkins, Kat. 2018. Nehanda, the Shona Spirit Medium That Inspired Mugabe. 16 October. https://www.bbc.com/news/av/world-africa-45877404.

Hyra, Derek S. 2017. Race, Class and Politics in a Cappuccino City. Chicago: The University of Chicago Press.

Jethro, Duane. 2020. Heritage Formation and the Senses in Post-Apartheid South Africa: Aesthetics of Power. Abingdon and New York: Routledge.

Keenan, Dennis Keenan. 2005. The Question of Sacrifice. Bloomington and Indianapolis: Indiana University Press.

Levin, Richard, and Daniel Weiner. 2008. The Politics of Land Reform in South Africa after Apartheid: Perspectives, Problems, Prospects. Journal of Peasant Studies 23 (2-3): 93-119. https://doi.org/10.1080/03066159608438609.

Makinana, Andiswa. 2019. Why Police Did Not Stop the Sheep Slaughter on Clifton Fourth Beach. 5 February. https://www.timeslive.co.za/news/ south-africa/2019-02-05-why-police-did-not-stop-the-sheep-slaughter-onclifton-fourth-beach/.

Mamdani, Mahmood. 2002. Amnesty or Impunity? A Preliminary Critique of the Report of the Truth and Reconciliation Commission of South Africa (TRC). Diacritics 32: 32-59. 
Maphanga, Canny. 2018. Clifton Beach Shut Down: 'We Did Not Close the Beach', Says Private Security Company. 26 December. https://www.news24. $\mathrm{com} /$ SouthAfrica/News/clifton-beach-shut-down-we-did-not-closethe-beach-says-private-security-company-20181226.

McDonald, David A., and Laila Smith. 2004. Privatising Cape Town: From Apartheid to Neo-liberalism in the Mother City. Urban Studies 41 (8): 1461-1484. https://doi.org/10.1080/0042098042000226957.

Naidoo, Leigh-Ann. 2016. Contemporary Student Politics in South Africa: The Rise of the Black-Led Student Movements of \#RhodesMustFall and \#FeesMustFall in 2015. In Students Must Rise: Youth Struggle in South Africa Before and Beyond Soweto'76, ed. Anne Heffernan and Noor Nieftagodien. Johannesburg: Wits University Press.

Nattrass, Nicoli, and Jeremy Seekings. 2001. Democracy and Distribution in Highly Unequal Economies: The Case of South Africa. Journal of Modern African Studies 39: 471-498.

Niehaus, Isak. 2014. Warriors of the Rainbow Nation? South African Rugby after Apartheid. Anthropology Southern Africa 37 (1-2): 68-80.

Pillay, Suntosh R. 2016. Silence Is Violence: (Critical) Psychology in an Era of Rhodes Must Fall and Fees Must Fall. South African Journal of Psychology 46: $155-159$.

Pinto, Sarah. 2006. Globalizing Untouchability: Grief and the Politics of Depressing Speech. Social Text 24: 81-102.

Rajgopal, Arvind. 2001. A 'Split Public' in the Making and Unmaking of the Ram Janmabhumi Campaign. In The Indian Public Sphere: Readings in Media History, ed. Arvind Rajgopal, 207-227. Oxford: Oxford University Press.

Rauch, Janine, and Storey David. 1998. The Policing of Public Gatherings and Demonstrations in South Africa 1960-1994. Accessed 17 February 2021. https://www.csvr.org.za/publications/1483-the-policing-of-publicgatherings-and-demonstrations-in-south-africa-1960-1994.

Schneider, Geoffrey. 2010. Neoliberalism and Economic Justice in South Africa: Revisiting the Debate on Economic Apartheid. Review of Social Economy 61: 23-50.

Shefer, Tamara, and Kopano Ratele. 2011. Racist Sexualisation and Sexualised Racism in Narratives on Apartheid. Psychoanalysis, Culture \& Society 16 (1): 27-48.

Tayob, Abdulkader. 2017. The National Policy on Religion and Education and Religious Dress Observances in South African Schools. In Religious Pluralism, Heritage and Social Development, ed. Christian M. Green, Rosalind I.J. Hacket, Len Hansen, and Francois Venter. Stellenbosch: SUN Media. 
Tayob, A. 2018. The Representation of Religion in Religion Education: Notes from the South African Periphery. Education Sciences 8 (3): 146. https://doi. org/10.3390/educsci8030146.

Turner, Richard. 1972. Black Consciousness and White Liberals. https://www. sahistory.org.za/sites/default/files/DC/rejul72.8/rejul72.8.pdf.

van der Veer, Peter. 1994. Religious Nationalism: Hindus and Muslims in India. Berkeley and Los Angeles: University of California Press.

- 2011. Spirit. Material Religion 7: 124-131.

Wagner, Keith B. 2015. District 9, Race and Neoliberalism in Post-apartheid Johannesburg. Race \& Class 57: 43-59.

Wells, Julia C. 2012. The Return of Makhanda: Exploring the Legend. Durban: University of KwaZulu-Natal Press.

Open Access This chapter is licensed under the terms of the Creative Commons Attribution 4.0 International License (http://creativecommons.org/licenses/ by/4.0/), which permits use, sharing, adaptation, distribution and reproduction in any medium or format, as long as you give appropriate credit to the original author(s) and the source, provide a link to the Creative Commons licence and indicate if changes were made.

The images or other third party material in this chapter are included in the chapter's Creative Commons licence, unless indicated otherwise in a credit line to the material. If material is not included in the chapter's Creative Commons licence and your intended use is not permitted by statutory regulation or exceeds the permitted use, you will need to obtain permission directly from the copyright holder.

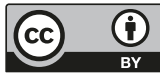

